\title{
Raimondi-Vignoli-Cristina. Poetic Activism in Contemporary Argentina.'
}

These reflections on the position of poetry in Latin American Cultural Studies today are in part inspired by experiences on a research trip to Buenos Aires, in April of 2011. Of particular interest was the great number of new poetry publishing start-ups, small presses, self-publishing, and community or activist projects based on poetry, as well as the number of poetry readings and book launches taking place.

After attending a poetry reading in the Boedo district, I met the young poet who had invited me. We talked at length about the political moment. Also involved in the conversation was another young poet, an activist and member of HIJOS, a group instrumental in restarting the trials of those who committed crimes against humanity during the 1976-83 dictatorship. Such groups have been a key part of the political phenomenon known as Kirchnerism; Néstor Kirchner and Cristina Fernández de Kirchner both incorporated HIJOS and similar groups' language and some of their demands into their own speeches and policies. The poet-activist is also a member of a group called Poetas con Cristina, Poets with Cristina, who formed in November 2010 as a spin-off from the marches to pay posthumous homage to Néstor Kirchner, and partly as an echo of the "Carta abierta" group of writers and intellectuals who have supported the elected government against, for example, the "campo" protests of the mid 2000s." As is well known, after Kirchner's death, Cristina strengthened her position, amongst many intellectuals, at the ballot box, and with a broad current of youth activism in her support; Poetas con Cristina is by no means the only group to explicitly suture poetry and political activism.

This conversation came to abrupt end with an argument: the young poet told the poetactivist that he was stupid and naive for being a member of Poetas con Cristina and for his 
enthusiastic support for the government, and for refusing to accept Kirchner's roots in what he saw as the corrupt and politically bankrupt legacy of Menemism. The poet-activist told the poet that he knew nothing as he had never been a militant and did not know his politics. There followed a rather awkward silence, which I tried to break by saying that there, in essence, was the problem for writers today in Argentina. If one is critical of the government, one risks providing grist for the conservative or neoliberal mill, or being labelled a "gorila"; while the available political alternatives, right and left, are unpalatable, unacceptable or unelectable.

To talk about recent Argentine poetry requires some cultural contextualisation. After the emergence in the 1980s of neobarroco or neobaroque poetry, and in the 1990s of a contrasting objetivista or objectivist aesthetic, commentators have written of "Boom" in poetry in the 2000s, the emergence or successful re-launching of young writers, notable anthologies, and new independent publishers, such as Mansalva, Paradiso, Vox, Argonauta, and Bajo la luna (Balaguer 2009; Carrera 2009; Freschi 2005; Mazzoni and Celci 2006; Epplin 2007). In many cases there is an explicit linkage between activism and poetry. Many groups and poets use poetry as an integral part of their activism: one thinks, for example, of the poetry workshops for inmates at the Ezeize women's jail, the Yonofui [sic] project.

One must underscore, then, the slightly paradoxical situation of Argentine poetry in the 2000s: in spite of the institutional disaster of $2001 / 2$, these exists a small yet quite solid public for poetry. Diario de poesía, for example, has been able to print and sell up to 5,000 bimonthly copies; independent publishers such as Bajo la luna, Vox, and Mansalva now have a certain status and trajectory, with editions of books of poetry running to 500 or even 1,000 copies, as well as varied and large back-catalogues. Economic crisis seemed to impose 
two necessities, to which poetry was able to respond well: firstly to find new means of circulation; and secondly to bypass the lack of official funding. Further, as in the case of the Argentine art market, the devaluation of the peso to a third of its pre-2001 value had the effect of favouring the export of locally produced books. As one editor I spoke to noted, before 2001, poetry publishers were little interested in exporting their books; but in recent years, sales to the US, Spain, and to a lesser extent Germany occupy a small but lucrative position on their balance sheets. Furthermore, poetry, in contrast with other forms of literature (not least the novel) is relatively cheap to produce, and its circulation lends itself well to new digital technologies. Craig Epplin has studied the links between contemporary poetry and digital communications technology, for example. At the same time, the writing of poetry, by means of requiring only the most basic primary materials, to wit a surface to write on and something to write with, tends to emerge in situations of material privation: hence the success of the proyecto Yonofui, mentioned above, and studied by Ross (2009: 6). Another notable example of what might be called carceral poetry is the work of Camilo Blajaquis, the pseudonym of César González, a young man jailed between the ages of 16 and 20, who published his first book, La venganza del cordero atado (Buenos Aires: Continente) in 2010, and who directs a poetry magazine and workshops in the district of Villa Carlos Gardel, and who has been a vocal public supporter of aspects of the current government's social plans. However, the aesthetic effects of such activist positions have not, I feel, been studied closely. The question that seldom addressed is whether there is coherence between the aesthetics and politics of such activist projects.

In her well known studies, Barbara Harlow $(1987,1996)$ talks of "revolutionary writing" to describe the almost symbiotic relationship between literary activity, in particular poetry, 
and revolutionary activity within the frame of armed national liberation struggles and in particular in their construction of imaginary communities (1987: 51); the most pertinent example here would be the life and work of the Salvadorean Roque Dalton, and his poetry, "not only made with words" (39). Well known are the criticisms of the models of writing that came to be imposed within the revolutionary and post-revolutionary context - one thinks, for example, of the exteriorismo promoted by Ernesto Cardenal as Minister of Culture in Sandinista Nicaragua, as described by Rowe (2000) or Gonzalez and Treece (1992). But in today's Argentina, and in spite of certain historiographic attempts to reevaluate and vindicate the armed struggle, in particular on the pages, for example, of the magazine Lucha armada en la argentina, or the important presence and influence of poets explicitly committed to forms of revolutionary politics (Juan Gelman, in particular), it is less credible to talk about the general existence of "revolutionary writing".

Another term available might be that of Doris Sommer, "cultural agency", employed to mean "a range of social contributions through creative practices", and the notion that the author employs to describe the space created by and in which cultural agency operates, namely "wiggle room". But I regard these as simply too broad to facilitate analysis of recent works; Sommer, for example, talks of "cultural agency" as part of democracy's "second nature" (19).

In this context, it might be more useful to talk of a form of "cultural activism" as defined by Crimp (1988: 12) in his work on the artistic responses to AIDS in the 1980s: collective, committed art that not only questions cultural production itself but also its position and forms of diffusions, and which criticises the use of art as simply a tool to collect funds, an act 
which for Crimp underlines and contributes to the commodification and commercialisation of interpersonal relationships.

For these and other reasons, the term "poetic activism" is adopted for this title, and to describe the emergence of these new forms of politically aware and motivated poetry in today's Argentina, of which Raimondi's work was a pioneer. The term is not original, although it is generally used in other fields and contexts. It is used here to refer to both a phenomenon and a context, and to describe something that does not appear to be accurately covered by existing terms which attempt to describe this meeting between poetry and political projects, a situation in which social or political activist projects adopt or use the writing, publishing and reading of poetry as a central plank in their discourse, activity, and identity, whilst poets situate their work explicitly within an activist context. In very general terms, we could note the way in which Raimondi's poems deal with the same themes that the Oral History museum, the Museo del puerto, Ingeniero White, Bahía Blanca, which for many years he ran, also deals with, such as industrialisation, colonialism, and the daily lives of people in the port. By focussing on "poetic activism" we are obliged to carry out an analysis of the poetics of these authors in order to examine whether the relationship between activism and poetry goes further than mere circumstance or surface, addressing the relationship between aesthetics and practice in contemporary authors.

Raimondi's collection Poesía civil, published in 2001, in some respects, marked the culmination of the flatly realist style known as 1990 s or objetivista poetry, but also set a marker for much poetry of the 2000s. Firstly, it was an eminently literary work, with references to Shelley, Keats, Dante, the English metaphysical poets, amongst others, and poems written in an epic form of long, measured lines with occasional rhyme. Secondly, it is 
metapoetic, reflecting on questions related to the status and role of poetry, in particular its social role; Gramsci, Brecht and Valèry are all referenced and engaged. Thirdly, it is closely linked to Raimondi's work at the Museo del Puerto.

The great ambition of Poesía civil is to analyse in verse not only modern industrial practices, the relationship between peripheral cultures and the centralising or excluding power of capital, but also the capacity of poems themselves to carry out the analysis that is being proposed. They respond, one might argue, to Theodor Adorno's insistence in Aesthetic Theory that modern works must show themselves to be equal to high industrialism, not simply to take it as a theme (2004:42), in particular through their ability to analyse complex industrial processes and economic relations using sophisticated forms of verse, but turned to other purposes. The first poem in the collection I would argue (and Raimondi does too) appears to define the aesthetic and political aims of the entire book, as a consideration of poetry's position in the world:

Ante un ejemplar de Defense of poetry con el sello "Pacific Railway Library, B. Bca., no 815 (to be returned within 14 days)"

\section{Escrito está en tus páginas}

que poesía y principio de propiedad

dos fuerzas son que se repelen,

pero escrito está también

que la poesía es infinita y divina,

no hay tiempo preciso ni lugar,

y el dominio que te concierne

verdadero es, eterno, único,

imperio sobre el universo todo. 


$$
\text { Oh, legislador del mundo, }
$$

no fuiste ignorado en absoluto,

es sólo que fuiste considerado

tal como exigías: se te dio el reino

preferido, el invariable, intangible

y perfectamente ideal;

el otro quedó para tus lectores,

dueños y destinados a regir

territorios más concretos del planeta.

(2001: 11)

Several aspects of the poem's composition demonstrate Raimondi's prosodic care, which today smacks somewhat of archaism. One notes, for example, the preponderance of hendecasyllabic lines, a measure cultivated by both modernistas and certain poets of the Spanish Golden Age. The poem's syntax consists of two long sentences, each of which covers nine lines of a poem whose entire length comes, rather neatly, to eighteen. The poem's syntactic structure shows a preference for subject-verb order, less common in colloquial Spanish than verb-subject, but with a resonance of English syntax, and with it Shelley's, and even the order subject-predicate-verb, even less common and more anachronistic. There is a certain excess or repetitiveness in the use of adjectives (not at all a 1990s or objetivista trait), for example "infinita y divina", at times with an exaggeration that might seem mocking or sarcastic ("preferido, invariable, intangible / y perfectamente ideal"), but which also reproduces the tendency found in literary English towards double or even triple adjectivization, a tendency that has its roots in the coexistence of synonyms drawn from Germanic and Romance languages in English lexis. There is a further preeminence of the phoneme /p/ as a link between apparently key words in the poem's 
argument, such as "página" and "poesía". And, finally, there are a number of rhymes, for example using the oxytone /a/ as final syllable of a line; as well as half-rhymes; and rhymes seemingly designed to highlight key words ("mundo", "absoluto"). The poem, thus, distances itself from everyday speech, making language strange, while at the same time mobilising formal and thematic elements of Percy Bysshe Shelley's source text. This distancing seems to support what might be read as the fundamental proposition of the poem: that the idealised and ideal poetry described by the Romantic Shelley, given status as legislator of the world, is removed from the day-to-day lives of readers by an unbridgeable gulf; and therefore Shelley's suggestions are mere ideology. Such a question, of the relationship between writing and reading works in verse and the humdrum daily round of its readers - if there are any - is most relevant for today's Argentine poetry. Poetry, as unacknowledged legislator of the world, in Shelley's terms, can instead become quite simply unacknowledged, period, which is to say, obsolete. Poetry, at the time of Raimondi's writing and publication, occupied a quite precarious position in the book market and in national cultural politics, while poets must struggle to publish or to make any sort of a living out of their work.

The paradox of Raimondi's poem would be, then, why present the utopian vision of the power of poetry held by a romantic poet as being an ivory-tower fantasy in a poem that is, to put it shortly, so very poetic? Indeed, the poem illustrates the means by which in the 2000s poets seem to overcome the perceived split between poetry committed to aesthetics and poetry committed to politics, a split which many have argued exists in the postvanguard period (Kuhnheim 1996). This is even more striking as the echoes of modernismo 
stage a conflict between poetry critical of the instrumentalisation of language in the modern industrial world and a description, throughout the collection, of that very world.

At this stage it is useful to turn to Raimondi's source text, Shelley's famous Defence of Poetry, written at the beginning of the 1820 s as a response to Thomas Love Peacock's satirical text, The Four Ages of Poetry (1820). One must note Raimondi's translation of one term above all: in English, the term "property", literal translation of "propiedad", appears nowhere in Shelley's tract. The term that appears in its place is "self." The line runs as follows: "Poetry, and the principle of Self, of which money is the visible incarnation, are the God and the Mammon of the world." "Self" is of course a difficult word to render into Spanish; options in bilingual dictionaries include "uno mismo", "de sí mismo", and "yo". Raimondi's translation, however, makes explicit something that is implicit in the English poet's essay, which is the relationship between poetry and communitarian or socialist forms of political organisation. The level of perfection achieved by the poetry and poets of an epoch demonstrates the perfection of the society; for example, and as Shelley indicates, "The true Poetry of Rome lived in its institutions"; the principal error of the contemporary era, for Shelley, was that science and technology had advanced so far, without the brake or control of suitable forms of poetry or expression. That is to say, man, for Shelley, has become the slave of his own technical inventions. In the second sentence quoted or paraphrased by Raimondi, "A Poet participates in the eternal, the infinite and the one", we can identify the source of the disagreement between the Argentine and the Englishman: if for Raimondi the eternalness and infinity of poetry imply a rupture with the real world, for Shelley, "if no new poets should arise to create afresh the associations which have been thus disorganized, language will be dead to all the nobler purposes of human intercourse." 
Poetry is the harbinger of a new, and better, socio-political era: "The most unfailing herald, companion and follower of the awakening of a great people to work a beneficial change in opinion or institution, is Poetry." For Shelley, a change in poetry accompanies or, better said, precedes social change.iii

It would be incorrect to talk of an error in Raimondi's reading for, as Pas indicates, one of the axes of the first part of Poesía civil is precisely a questioning of romanticism (2007:5). In a personal communication (2010a), Raimondi expanded on the importance of the poem, quoted above, within his work: if Romanticism, in particular "that" Romanticism, as Raimondi calls it with reference to Shelley, coincides with the emergence of industrial society, in opposition to it, yet also with the support of its inventions and capital, Romanticism is also a point of departure for modern poetry in Latin America ("este lado del mundo" [this side of the world] he called it); thus a re-examination of the relationship between poetry and industry offers a potential starting point for poetry capable of dealing with geopolitical questions (2010a).

In an article on the work of the nineteenth-century liberal Juan Bautista Alberdi, Raimondi quotes liberally from Shelley; this encounter between Shelley and Alberdi "opens up the possibility of interrogating the universal rule of literary concepts with the universal division of production as a determining perspective" (2010b: 1 ); that is to say, the universal values predicated by Shelley are only universal within a given context, specifically a society with sufficient levels of development and technology to permit leisure, travel, and the free exchange of ideas and cultural products, for example. And whilst Shelley wants to separate poetry from the sphere of production, for Alberdi, literature is, precisely, another manufactured good (Raimondi 2010b: 3). Raimondi sketches the division of labour proposed 
by Alberdi between literary-producer and literary-importer countries, which of course follows closely that between primary or extractive industrial countries and those with more advanced sectors, in particular industrial production, such as, precisely, the England of the Romantic period (more or less contemporary with the Industrial Revolution, as Raimondi also points out in a subsequent poem, "Poética y revolución industrial” (2001: 13)). Raimondi argues that, beyond Alberdi's proscription against the importing or imposition of literary styles inappropriate for a pre-civilised country, as according to Alberdi the Provinces of the Río de la Plata were at that moment, "one must detect the possibility of thinking of the (economic, social, political, cultural, etc) circumstances as defining values for what poetry is" (Raimondi 2010b: 9).

Who then, are the readers of Shelley's tract in Raimondi's vision? They are at once the narrative voice of the poem; the contemporary Argentine or Bahian, reading the longoverdue or withdrawn library book either first or second-hand; and, critically, the member of the Pacific Railway library. The Pacific Railway, or Buenos Aires and Pacific Railway (BA\&P), owned the line from Buenos Aires to Bahía Blanca, part of a network that stretched across Argentina and as far as Chile (hence "Pacific"), one of the most important of a phalanx of British companies that owned the railways in Argentina from the Victorian era until nationalisation under Perón in the 1940s, followed by privatisation and effective dismantling under Menem in the 1990s, and were integral to the export industry that developed in the country and the port of Bahía Blanca. ${ }^{\text {iv }}$ Raimondi's irony is that the readers of Shelley's work in the edition he holds were precisely the legislators not of an ideal world, but of the new American territory, via concessions and contracts, and the ideology of free 
trade; while his contemporary reader, the struggling poet, is anything but. Raimondi's work therefore forces the reader's attention towards the context and situation of aesthetics.

One can, therefore, reread Raimondi's poem: in spite of the fact that "propiedad" is not the only or indeed even the most appropriate translation of "self", one must bear in mind that the genesis of the individual, and of identity, of self, has its roots in concepts of citizenship based on the ownership and protection of property and, in the Latin American case, in the ownership of land, and in most cases the ownership of land in the form most beneficial to colonizers or foreigners. The rebellion against Mammon (read: money, or, better said, capital) proposed by Shelley is based on changes, development, technologies and forms of communication that simply do not exist in other places. Furthermore, it has its material bases in the colonization of other countries, in particular countries that export primary goods. The poet can only rebel against Mammon because of surplus value extracted elsewhere. At the same time, the change makes clear that this is Shelley the revolutionary, Shelley the favourite poet of the Chartists, Shelley the strident critic of the repression of the worker, who is of interest and profit to the writer under conditions of neo-colonialism. The poem works dialectically on Shelley's romantic rebellion, putting it into contact with its material bases and rethinking poetry for the writer today in Argentina.

The writing of poetry, then, for Raimondi, for these reasons, should include the analysis of the conditions and effects, both historical and current, of colonization: here we see the link between Raimondi's poetics, the activist role proposed for his poetry, and the work of the Museo del Puerto. Raimondi's poetry is almost inseparable from his cultural work; since the late 1980s, Raimondi and others have worked in Ingeniero White to collect the stories and artefacts of people living around the port, including an entire barber's shop supplied by the 
poet Jorge Boccanera, who grew up locally. The museum aims to demonstrate the ways in which the practices of everyday life exist in a tense and conflicted relationship with national and international politics; it dedicates its efforts to the recuperation and archiving of oral history and cultural forms not necessarily favoured by conventional museums, including typical local forms of cooking. Another of the Bahían poets, Aldo Montecinos, has published as well as poetry books, collections of oral history and local recipes. The critical texts that illustrate the museum's exhibits have something unmistakeably Raimondian about them, as well as a certain iconoclastic humour. The museum is, furthermore, an important centre for local cultural activities. It is staffed mostly by senior women; it runs a market on Sundays; it plays host to musical events; it attracts many visitors and tourists, in particular to the afternoon teas. All of which is a way of saying that, as accomplished as Raimondi's poetry may be in prosodic terms, it is still poetry that, as Jacques Rancière might put it, "assumes its insufficency" (2010: 149), or, as in this case, proposes a parallel work shared between poetry and activism.

Raimondi's poetry, however, is not without its critics; perhaps the most strident of these can be found in Beatriz Vignoli's 2003 review of this collection. Vignoli acknowledges the importance of Raimondi's book but attacks what she sees as a confusion or reversal of form and content, one that has its roots in the work of oral history carried out by Raimondi in the local museum, by which the poet, working as an unproductive employee of local government - and Vignoli draws particular attention to the fact that this is a Peronist local government - treats poetry as a metal detector and his or her own role as something like that of a customs overseer (and a Soviet one at that), a pointed reference to the Museum's site in the former aduana of the port (278). But Vignoli goes further, seeing the totalising 
vision of Poesía civil (in the sense of writing and collecting the entire life of a community) as Soviet in ambition, while the writer converts himself into a petty bureaucrat (274); elsewhere, she accuses him of committing the same "error de juicio" committed by the Nazis in condemning impressionism as degenerate art (274).

Although Vignoli's ad hominem attack on Raimondi is no doubt exaggerated and wide of the mark, too busy attempting to land passing blows on large sectors of the provincial cultural and political establishment to spot irony or nuance in the collection it reviews, it strikes at the heart of a dilemma for those employed by the state on cultural projects, or who write with links to state-funded cultural projects, to wit, how to maintain a critical position? Vignoli's criticism, furthermore, takes us back to the argument with which this paper began: what relationship should, or can, poetry and poets maintain with popular left-ist, or left-ish, governments?

Here I would like to suggest that poetry is a privileged case study for the relationship between politics and the arts in contrast, for example, to prose fiction, but not for the reasons that Vignoli would like to suggest. Josefina Ludmer, in her 2010 volume, Aquí América Latina, argues that today when one talks about writing in Latin America, categories such as reality and fiction can become quite meaningless; this flatly realist, internationalist, contemporary fiction dominates the output of major publishing companies, most of which are multinationals, and many of which see the Spanish language as a huge potential source of profit. These are works that for Ludmer are post-autonomous, that despite all their literary references can no longer be judged, indeed have no intention of being judged, by the classifications of literary studies; one cannot say if a novel by Bellatín, or Alan Pauls, or Chejfec, or César Aira is good or not, or rather there is no point doing so, as if it is bad it 
might be deliberately so. One remembers that Vignoli's attack on Raimondi drew a contrast between his collection and "la esfera de la autonomía de lo poético" (274) or "poesíapoesía" (281). However, it is highly revealing that, although one might assume that works such as those of Raimondi would fit within Ludmer's scheme, given his use, for example, of eminently un-poetic subjects, such as industrial fishing, railway fire regulations, or legislation on horse-drawn transportation, these poetic works are not mentioned. Indeed in the diary section of Aquí América Latina, Ludmer recounts a conversation with Tamara Kamenszain in which, after the poet has offered a reading of today's "unpoetic" poetry, Ludmer deliberately withdraws from the topic of conversation and never mentions poetry again in the work. For those who have followed Ludmer's career, in particular her seminal study of the gauchesco, with its extraordinarily sensitive reading of gauchesca poetry, including of course Martín Fierro, her repeated resistance to reading poetry may appear surprising. One might imagine, perhaps, that the distinction between the epic and the lyric plays a part in this critical decision. This elision of poetry seems to relate more specifically to a reliance on Kant's ideas on literature's autonomy; for Kant, who, we must remember, ranked poetry as holding the "first rank" of all the arts (155), "fine art must be free in a double sense" (150), not only the result of the mind occupying itself without any end, but also in the sense of being "opposed to remunerated work" (150). "As Ludmer is applying categories drawn from Kant to art-works to which they may not necessarily be applied, specifically the commercial novel, perhaps the inclusion of poetry in her panorama would too clearly underscore this contradiction in her argument, given poetry's different modes of circulation and reception, and its awkward contemporary relationship to commercialisation. Raimondi's work is worthy of attention in this regard for several reasons: first, his is poetry that must be read as poetry, not simply a medium for social comment. Returning to 
Adorno's words, above, regarding artworks making themselves "equal to high

industrialism," formal questions as well as thematic ones are at the forefront of Raimondi's poetry. This is vital; otherwise we cannot progress beyond the debate over "poesía social" and the Sartrean commitment to plain expression. The line length and cadence of Raimondi's poem suggest a form of popular epic, after Brecht. The irony of tone, found in this poem and throughout the collection, takes the promises of developmentalism at their word, only to see them fall short, while at the same time following in a tradition of ironic black humour that begins with Echeverría's El matadero. The narrative voice - one that echoes the information displays at the Museo del Puerto, with its knowing, schoolmasterly airs - trumps industrialism's knowledge of its self. His syntax, with its Romantic and Anglophone forms, occupies Shelley's source text and the poetry of the Englishman and his peers. Secondly, the reading of society that it does carry out is ironic, layered, and multifaceted, as well as being highly critical; to do this - thirdly - he demonstrates a keen awareness of the position of the writer and writing in local and global networks of economic and political power; and, finally, it is poetry that is part of a broader community project.

To this end one might attempt to offer some conclusions about poetic activism and its relationship to Latin American Cultural Studies. As it is hoped has been shown, Raimondi's poetry echoes, or responds, quite directly, to the work being carried out at the Museum. The relationship that this has to the wider political sphere is a complicated and at times difficult one. Here I think we can find a useful descriptive term in a recent text by David Wood and Cornelia Gräbner, who speak of "porous autonomy". According to Wood and Gräbner, porous autonomy differs from artistic autonomy as proposed by Theodor Adorno, given that it no longer occupies a third space, independent from the two great ideological 
blocs (Western Capitalism and Soviet Communism), but rather a resistant space within the globally hegemonic neoliberal system, a form of autonomy without purity, neither distanced nor wholly outside of ideology, but open, and in which artists interact with social and political configurations. One might add that, following Ludmer, we might find a postKantianism that does not describe something immediately recuperable for commercial profit. Rather than a poetic resistance, a term that I and others have used elsewhere to describe, for example, poetic activism carried out by Mapuche peoples or poets in the Western Sahara, this porous autonomy is the site of poetic activism within a context, namely Kirchnerismo, that is in many respects rather more favourable to community projects, grassroots organisation, or the recuperation of historical memory, as Svampa (2008) notes. Poetic activism, thus, is a means of linking poetry and activism as mutually porous autonomies; or, as Giunta puts it, "the work is not political for its themes, but rather for the social support that sustains it" (2009: 68); or, as Eduardo Milán writes, "poetry in Latin America always looks like an activity of emergency, in two senses: that of emerging and of the call to attention regarding limit situations" (2004: 9). In this case, the limit is that between creative activity and political activism. There is, thus, something like a symbiotic link between activism and poetry: one cannot exist without the support of the other, whilst their mutually porous autonomy demonstrates awareness that neither activism, nor poetry, is in itself autonomous or sufficient.

What of the work of cultural studies, then? Latin American Cultural Studies boasts a subset of writings on the relationship between the state and poetry, in particular the relationship between poetry and post-revolutionary political projects; Cardenal's role as Sandinista Minister for Culture and his promotion of poetry workshops as part of a wider literacy drive 
has already been noted. We could also, perhaps, see the end of the first Sandinista government as the initial or even inaugural crisis for Latin American Cultural Studies. Those of us who pursue Latin American Cultural Studies and work on poetry in the UK have as reference points two works that consider this constellation, Rowe's History and the Inner Life and Gonzalez and Treece's The Gathering of Voices. If for Rowe, Cardenal's poetry runs aground on God - or "Nothing" with an upper case N, as opposed to "nothing" in the lower case - for Gonzalez and Treece the problem is rather the reader or the critic, who miss the point of Cardenal's project. Might Raimondi, as Vignoli argues, reef on Kirchnerismo, not least given that many of the aspects on which Raimondi most closely focuses his attention, including the role of multinationals, and more particular extractive industries are precisely some of the most problematic policy areas for contemporary "pink tide" governments in Latin America, as crystalised in the recent case of the Osisko mine in the La Rioja town of Famatina? ${ }^{\mathrm{vi}}$

Raimondi's projects, and many other poetic-activist projects, operate with a form of state support, that of a democratically elected government, at regional or federal level, that is by no means revolutionary, has only limited if any practical links to armed struggle, mostly discursively, but at times in practice operates against the neoliberal model that those of us doing Latin American Cultural Studies so often say we too are against; perhaps ironically, we carry out our work at a moment in which the countries we study turn away from the model that leads central countries to dismantle the very system that allowed us to study them in the first place (namely, state-supported teaching and research in the arts and humanities). But his poems also suggest an immanent critique of poetry; this could be salutary for Cultural Studies still tempted by Romanticism. Raimondi knows that one person writing 
poetry, like one person carrying out Cultural Studies, is in itself largely insignificant, that, as Juan Gelman once observed, one does not take power with a poem. And yet, one writes the poem all the same, and as part of something of wider range and scope than solo lyric poetry, cultural analysis and literary production start to become significant.

What is being posed, then, is a methodological question: how do we read? The answer that I'm proposing might seem to be an Adornian circle; Cultural Studies is born, as it were, of an anti-Adornian gesture, a refusal to discard popular culture as mere kitsch; but today it is the return of Adorno, in Aesthetic Theory, to haunt himself, that offers important tools and terminology for our work. In a sense, the shuttle between oral history (often using everyday consumer objects) and finely wrought poetry, as seen in Raimondi's work, is the same Adornian journey that matters to us as Cultural Studies practitioners. As Adorno remarks, with great irony, "Can anyone but a philistine, you will ask, talk about lyric poetry and society?" (1974a: 56). He subsequently goes on to demonstrate that the "meaning" of the poem emerges when, because of its defined aesthetic form, it takes part in "the generality of things" (56). As Adorno remarks, "the thinking through of a work of art justly requires a concrete inquiry into social content" (57). A work is to be examined to see both how it is true to its society and how it may transcend it; some works may only find their truth years after their publication. Lyric poetry is always caught in a paradox; on the one hand, it cannot be "deduced from society", its spontaneity is such that it exceeds the conditions of the moment; yet through this spontaneity, the work of the individual, "objective historical forces rouse themselves within the poem" (61). "The truth content of artworks", Adorno argues in Aesthetic Theory, "is the unconscious writing of history bound up with what has until now been repeatedly vanquished" (2004: 251). It is this "unconscious writing of 
history" that interests me, and that I hope the close reading of poetry in its political and social context may serve to make explicit. ${ }^{\text {vii }}$

But this is also another question, a pragmatic one: what does one say about the argument in a bar with which these reflections began? If critical support for the revolutionary left is somewhere in the DNA of Latin American Cultural Studies, the question we must ask ourselves is how we can find a match, or accommodation, or even productive tension, between our socialism and feminism and democratic left-leaning governments in power? John Beverley has argued that we need to recuperate the memory of the armed struggle, as a "flawed but tragic enterprise, but also a brave but generous one" (2009: 59). Raimondi's work, with its attention to the everyday struggles and daily practices of those living in a site criss-crossed by movements of capital and power, with its poeticization and sharing of the meeting place between a precisely situated popular memory and international politics, I would argue, is the start of an answer. We await his next collection with eager anticipation; in the meantime, his work offers a lesson for today's Latin American Cultural Studies. 


\section{Works Cited.}

Adorno, Theodor. 2004. Aesthetic Theory. trad. Robert Hullot-Kentor. London: Continuum.

Adorno, Theodor. 2000. Problems of Moral Philosophy. Trans. Rodney Livingstone.

Cambridge: Polity.

Adorno, Theodor. 1974a. "Lyric Poetry and Society." Telos 20 (Summer 1974): 56-71.

Adorno, Theodor. 1974b [1951]. Minima Moralia. Reflections from Damaged Life. Trans.

E.F.N. Jephcott. London: NLB.

Adorno, Theodor. 1967. Prisms. Trans. Samuel \& Shierry Weber. London: Neville Spearman.

Aguirre, Carlos. 2009. "Hegemonía." In Szurmuk, Mónica and Robert McKee Irwin (eds).

Diccionario de estudios culturales latinoamericanos. Mexico City/Buenos Aires: Instituto Mora/Siglo XXI: 124-30.

Balaguer, Miguel. 2009. Interview with author, Corner Bar, Abasto, Buenos Aires (22 November 2009).

Beverley, John. 2009. "Rethinking the Armed Struggle in Latin America." boundary 2 36.1: 47-59.

Budde, Robert. 2010. "New tactics in Poetic Activism: Reg Johanson's Escratches [sic]." The Poetic Front. 3 http://journals.sfu.ca/poeticfront/index.php/pf/article/view/26 [last accessed 19 November 2010].

Carrera, Arturo. 2009. Interview with author, "La barra," Buenos Aires (23 November 2009).

Carrera, Arturo. 2008. Las cuatro estaciones. Buenos Aires: Mansalva.

Carrera, Arturo (ed.). 2001. Monstruos. Antología de la joven poesía argentina. Buenos Aires: FCE.

Collins, Richard. 1998. “Andrei Codrescu's Mioritic Space.” MELUS 23.3: 83-101.

Crimp, Douglas (ed.) 1998. AIDS. Cultural Analysis. Cultural Activism. MIT.

Cucurto, Washington. 2009. El tractor. Buenos Aires: Eloísa Cartonera.

Davis, Mike. 2001. Late Victorian Holocausts. El Niño Famines and the Making of the Third World. London: Verson, 2002.

Epplin, Craig. 2010. "Poetry, Potlatch and Site: Arturo Carrera's Estación Pringles." Journal of Latin American Cultural Studies 19.2: 187-202.

Epplin, Craig. 2007. "New Media, Cardboard and Community in Contemporary Buenos Aires." Hispanic Review (Autumn 2007): 385-398. 
Fernández, Nancy. 2006. “Cucurto y Zelarayán." el interpretador no. 29, Dec. 2006

http://www.elinterpretador.net/29NancyFernandezCucurtoYZelarayan.html [last accessed 3 December 2010].

Freschi, Romina. 2005. "Recomposición del campo poético argentino y poesía actual." La jornada semanal 16 de octubre de 2005. http://www.jornada.unam.mx/2005/10/16/semromina.html [last accessed 19 November 2010].

Friera, Silvina. 2010. "Es más peligroso un pibe que piensa que un pibe que roba." Página12. 18 October 2010. http://www.pagina12.com.ar/diario/suplementos/espectaculos/4-196412010-10-18.html [last accessed 19 November 2010].

García Helder, Daniel. 1987. "El neobarroco en la argentina." Diario de poesía no. 4 http://ustedleepoesia2.blogspot.com/2009/08/el-neobarroco-en-la-argentina.html [last access 19 November 2010].

Gergen, Kenneth. 1999. An Invitation to Social Construction. London: Sage.

Giunta, Andrea. 2009. Poscrisis. Arte argentino después de 2001. Buenos Aires: Siglo XXI.

Gonzalez, Mike and David Treece. 1992. The Gathering of Voices: The Twentieth-Century Poetry of Latin America. London/New York: Verso.

Gräbner, Cornelia and Wood, David. "Poetics of Resistance: An Introduction." In Cosmos and History, special edition, "Poetics of Resistance", January 2011.

Hallward, Peter. 2001. Absolutely Postcolonial. Writing between the Singular and the Specific. Manchester UP.

Harlow, Barbara. 1996. After Lives. Legacies of Revolutionary Writing. London/New York: Verso.

Harlow, Barbara. 1987. Resistance Literature. London/New York: Methuen.

Jameson, Fredric. 2005. Archaeologies of the Future. The Desire Called Utopia and Other Science Fictions. London: Verso.

Kuhnheim, Jill S. 1996. Gender, politics, and poetry in twentieth-century Argentina. Florida UP.

Laddaga, Reinaldo. 2006. Estética de la emergencia. Buenos Aires: Adriana Hidalgo.

Lewis, Colin M. 1983. British Railways in Argentina 1857-1914: A Case Study of Foreign Investment. London: Athlone Press.

López-Adorno, Pedro. 1987. 'La lectura ideológica-estética de "Altazor."' Revista de Crítica Literaria Latinoamericana 13. 25: 51-80.

Lucha armada en la argentina see http://www.ejercitarlamemoria.com.ar/lucha/index.html [last accessed 23 Dec 2011].

Ludmer, Josefina. 2010. Aquí América Latina. Buenos Aires: Eterna Cadencia. 
Ludmer, Josefina. 2007 (?). "Literaturas postautónomas."

www.lehman.cuny.edu/ciberletras/v17/ludmer.htm [last accessed 17 Sep 2009].

Martyniuk, Claudio. 2009. "La poesía es arte de esperanza; restaurar una estación de tren, también." Clarín, Zona. 29 March 2009, pp. 32-3.

Mazzoni, Ana and Damián Selci. 2006. "Poesía actual y cualquierización." el interpretador 26 http://www.elinterpretador.net/26AnaMazzoniYDamianSelci-

PoesiaActualYCualquierizacion.html [last accessed 28 Dec 2011].

Milán, Eduardo. 2004. Resistir. Insistencias sobre el presente poético. 2nd ed., México DF: FCE.

Moreiras, Alberto. 2001. The Exhaustion of Difference. The Politics of Latin American Cultural Studies. Durham/London: Duke.

Parker, Martin, Valérie Fournier and Patrick Reedy. 2007. The Dictionary of Alternatives. Utopianism and Organization. London/New York: Zed.

Pas, Hernán. 2007. “Una materialidad de la exasperación. Acerca de Poesía civil, de Sergio Raimondi." Orbis Tertius XII (13).

Porrúa, Ana. 2007. "Poéticas de la mirada objetiva." Crítica cultural 2.2

http://www3.unisul.br/paginas/ensino/pos/linguagem/critica/0202/03.htm [last accessed 19 November 2010].

Porrúa, Ana. 2005. "La novedad en las revistas de poesía: relatos de una tensión especular." Orbis Tertius, 2005, $\mathrm{X}(11)$

Prieto, Martín. 2009. “Neobarrocos, objetivistas, epifánicos y realistas: Nuevos apuntes para la historia de la nueva poesía argentina." VOX virtual 23 (julio 2009)

http://www.revistavox.org.ar/virtual 23.htm\#Prieto [last accessed 2 Dec 2010].

Prieto, Martín. 2002. "Reportaje a Washington Cucurto. Arrebatos en el conventillo." http://proyectov.org/venus2/index.php?option=com content\&task=view\&id=259 [last accessed 2 Dec 2010].

Raimondi, Sergio. 2001. Poesía civil. Bahía Blanca: Vox.

Raimondi, Sergio. 2010a. Personal communication via email with author. (3/1/10).

Raimondi, Sergio. 2010b. "Poesía y división internacional del trabajo. Sobre Estudios económicos de J. B. Alberdi." Revista planeta 1.

http://plantarevista.com.ar/anteriores/nr1/raimondi.html [last accessed 16 Nov 2010].

Rancière, Jacques. 2010. Dissensus. On Politics and Aesthetics. Trans. Steven Corcoran.

London: Continuum.

Ros, María Ofelia. 2010. "The Uncanny Laughs Once Again: Subjectivity and Structures of Ideological Domination in Late Twentieth-Century Argentinean Cultural Production." PhD Thesis, University of Michigan 
http://deepblue.lib.umich.edu/bitstream/2027.42/77678/1/ofeliar 1.pdf [last accessed 19 Nov 2010].

Ross, Laura, 2009. “Contra el silencio." Confines- El extremo sur de la Patagonia. 20: 6-8.

Rossel, Ana, et al., 2006. Yo no fui. Antología poética. Buenos Aires: Voy a salir y si me hiere un rayo.

Rowe, William 2000. Poets of Contemporary Latin America: History and the Inner Life. Oxford UP.

Seoane, María. 2003. El saqueo de la argentina. Buenos Aires: Sudamericana.

Shelley, Percy Bysshe. A Defence of Poetry (1821/1849). http://www.thomaslovepeacock.net/defence.html [last accessed 2 Dec 2010].

Sommer, Doris, 2006. "Introduction." In Cultural Agency in the Americas. Durham/London: Duke, pp1-28.

Stones, H. R. 1993. British Railways in Argentina 1860-1948. Bromley: P.E. Waters.

Svampa, Maristela. 2008. Cambio de época: movimientos sociales y poder.Buenos Aires: Siglo XXI.

Svampa, Maristella and Mirta A. Antonelli (eds). 2009. Minería transnacional, narrativas del desarrollo y resistencias sociales. Buenos Aires: Biblos.

Vignoli, Beatriz. 2003. "Abolición del limbo" (Review of Sergio Raimondi, Poesía civil). Hablar de poesía 9: 273-284.

\section{Notes.}

\footnotetext{
'I am grateful to Philip Derbyshire, Cornelia Gräbner, and David Wood, for their comments on earlier drafts of this paper. An edited version was presented at the University of Texas at Austin in March 2012, and I thank Lorraine Leu for the invitation to speak there.

ii Carta abierta is a left-of-centre grouping of intellectuals and cultural figures that emerged to support the democratically elected government in the face of what it perceived to be reactionary and anti-democratic protests. The group publishes periodical "open letters" on political matters (hence the name) and has a website http://www.cartaabierta.org.ar/nueva/. The "campo" protests were a series of large organized demonstrations by landowners, agro-industry bosses, rural workers, and their supporters, against windfall taxes on export profits.

iii Very similar claims have been made over the years for Latin American Cultural Studies itself, as Carlos Aguirre (2009: 129) observes in his entry on "Hegemonía" in the Diccionario de estudios culturales latinoamericanos.

iv See Lewis (1983) or Stones (1993) on the history of British ownership of Argentine railways; the other side of this story of colonialist infrastructural development and agricultural export is told by Davis (2001) in his history of el niño famines in the late Victorian era, "the fate of tropical humanity at the precise moment (1870-1914) when its labor and products were being dynamically conscripted into a London-centered world economy" (9); as he states elsewhere, "the use of force to configure a 'liberal' world economy [...] was what Pax Britannica was really about" (295).

${ }^{\vee}$ For a critique of Kant's account of autonomy, see Adorno (2000), esp. pp 80-81 and 118-20.

${ }^{v i}$ See, for example, Svampa \& Antonelli (2009) for an analysis of the relationship between state, private companies, and local resistance, in the question of "megaminería", or large scale open-cast mining.
} 
vii Or, put more simply, as Catherine Boyle would say to me when I was her student, we have to read closely, and we have to do something with our reading. 